\title{
Nutritional Properties of Native Plants and Traditional Foods from the Central United States
}

\author{
Kelly Kindscher ${ }^{1 *}$, Leanne Martin ${ }^{1}$, Steve Corbett ${ }^{2}$, and David Lafond ${ }^{3}$ \\ ${ }^{1}$ Kansas Biological Survey, University of Kansas, Lawrence, USA. ${ }^{2}$ Kansas Health Institute, Topeka, USA. ${ }^{3}$ Lafond Food \\ Technology LLC, Galesburg, USA. \\ *kindscher@ku.edu
}

\begin{abstract}
Traditional foods of indigenous people are a potential untapped source for providing nutritious dietary options in the modern world. The rising popularity of indigenous foods such as amaranth in recent years suggests that these foods can become a popular part of a healthy diet in the United States. Traditional knowledge of indigenous people can form the basis for using wild food resources. This research provides data on 50 plant species common to the central United States that are abundant sources of dietary protein and fiber, and used traditionally by Native American tribes. Many species show promise with high amounts of protein and fiber being found in lamb's quarters, nettles, grass seeds, and buffalo gourd seeds. These results honor traditional knowledge. In addition, many of these species could be cultivated using techniques similar to those existing for commercial grains and vegetables. Seeds and/or greens of these wild plants could easily be incorporated into the diets of many more people, improving modern diets, and the nutritional quality of food products.
\end{abstract}

Received January 4, 2018

OPEN ӘACCESS

Accepted August 6, 2018

DOI 10.14237/ebl.9.2.2018.1219

Keywords Fiber, Protein, Native plants, Ethnobotany, Wild foods, Indigenous diet

Copyright (C) 2018 by the author(s); licensee Society of Ethnobiology. This is an open-access article distributed under the terms of the Creative Commons Attribution-NonCommercial 4.0 International Public License (https://creativecommons.org/licenses/by-nc/4.0), which permits non-commercial use, distribution, and reproduction in any medium, provided the original author and source are credited.

Supplementary Files available at ojs.ethnobiology.org/index.php/ebl/article/view/1219

\section{Introduction}

Many food sources utilized in the past by Native American people are no longer consumed, despite their potential to provide high amounts of many nutrients that could benefit human health. Archaeological evidence indicates seeds of native lambsquarters (Chenopodium berlandieri) and marsh elder (Iva annua) were once cultivated as a part of the Eastern Agricultural Complex and used extensively in the Midwest and Great Plains, but these are no longer used as food (Asch and Asch 1977; Black 1963; Gremillion 2004; Kindscher 1987). Other foods, such as "greens" from Chenopodium, Amaranthus, and even common milkweed (Asclepias syriaca) are not consumed as much as they were decades ago by Native Americans. Many of these food sources may be more nutritious than foods we currently eat (e.g., Phillips et al. 2014), particularly with regard to protein and fiber content, of which the importance for health in human diets, is well-known (Nestle 2006). Therefore, there is a tremendous opportunity to improve the nutritional quality of modern diets while recognizing the value of traditional knowledge and practices by encouraging use of these wild foods today.

By "traditionally" used foods, we mean those that were eaten for centuries prior to contemporary history and consisting mostly of native plant species and some naturalized species, such as dandelions, thought to have arrived in North America with early European colonists (Sanchez 2007). Native Americans relied on wild plant foods for millennia prior to the development of the Eastern Agricultural Complex around $1800 \mathrm{BCE}$ and cultivated the seed crops, lambsquarters and marsh elder, as well as sunflowers, squash, little barley, and erect knotweed (Gremillion 2004; Smith and Yarnell 2009). Maize, beans, and new varieties of squash from Mexico, which were gradually adopted between 2000 and 200 BCE, became more widespread during the Woodland Period and were the dominant crops by $900 \mathrm{CE}$ throughout much of North America, which extended 


\section{Research Communications}

well into the historic period (Hart and Lovis 2013; Scarry and Scarry 2005; Smith 1989; Smith and Yarnell 2009). Consumption of these various traditional foods declined during the nineteenth and twentieth centuries with the influx of Euro-American foods and market subsistence (Mihesuah 2003).

New plant foods could promote human health and well-being through use as protein sources. Individual average protein intake in the United States is close to recommended amounts, though consumption of protein sources varies greatly relative to current recommendations. Most commonly consumed sources of protein are beef, chicken, pork, processed meats, and eggs. United States government recommendations encourage consuming more nutrient-dense foods, including leaner and lower sodium protein sources as a means to achieve healthier eating habits. More vegetable- and seedbased sources of protein are encouraged (US DHHS 2015), which would resemble a more traditional diet.

New and under-used dietary fiber sources could address the need to increase human consumption of fiber. Insoluble and soluble sources of fiber are important for a healthy diet. Less than ten percent of the United States population consumes recommended levels of fiber (Moshfegh et al. 2005; US Health and Human Services 2015). The addition of fiber to the diet is important for a variety of health reasons, including reducing the risk of certain types of cancer, improving gastrointestinal health, improving glucose tolerance and insulin response, and improving feeling of fullness for appetite suppression (Slavin 2008). Current information on what constitutes a healthy diet recognizes traditional food knowledge and encourages reconsideration of wild foods.

We know little about the nutritive values of many indigenous foods and how they compare to each other and to commonly consumed modern foods, although there have been some studies, such as Phillips et al. (2014), who examined ten species from the northern Plains, and Kuhnlein (2000) who studied traditional diets in Canada and documented the difficulties of studying traditional foods. The Midwest and Great Plains are rich in biological diversity and traditional knowledge of native plants (Kindscher 1987, 1992). And overall from these studies and others, current information on what constitutes a healthy diet indicates that many of the foods known from the ethnography and archeology of Indigenous communities would be welcome additions to contemporary cuisines.

The objectives of this research were to: 1) identify and collect native and a few naturalized plants that were traditional indigenous foods and have potential as commercial healthy food products; and 2) analyze the plants for dietary fiber and protein content.

\section{Materials and Methods}

\section{Species Selection}

We used ethnobotanical, phylogenetic, and chemical evidence to maximize the likelihood of finding native or naturalized plants with high values of fiber and protein. Specific to the ethnobotany approach, we used our Native Medicinal Plant Ethnobotany Database (Kindscher et al. 2013a) that we created for Great Plains and Midwest plants to look for species that were traditionally used by indigenous cultures for food, and that might contain high levels of protein or fiber. Our database documents regional Native American ethnobotany and it currently has 21,000 medicinal, edible, dye, fiber, and other uses recorded for nearly 1,450 plant species. We also used Daniel Moerman's (2013) database, which is a national ethnobotany database that includes medicinal and edible uses for some plant species that were not in our database. With this combined list, we used Dr. Duke's Phytochemical and Ethnobotanical Databases to determine whether there were any leads to finding protein- and fiber-rich plants and included those and related species for confirmatory testing (USDA 2013). These databases have information compiled on species-specific traits, such as their chemistry. For the phylogenetic approach, we considered species lacking extensive ethnobotanical records on their use as food, but that have the potential to be important food sources based on knowledge about closely related species. For example, psyllium seed, commonly used as a fiber source, is a Eurasian species of the genus Plantago, so we tested seeds from a native Plantago species.

Plant species were also selected based on previous chemistry research indicating safety. For example, even though jimsonweed (Datura sp.) plants appeared to have high protein content, as well as other interesting chemistry discovered previously (Zhang et al. 2013), we did not pursue this plant due to its poisonous properties (Preissel 2002). For all plant species collected, we used our Ethnobotany database to compile a table of the most common food use of 


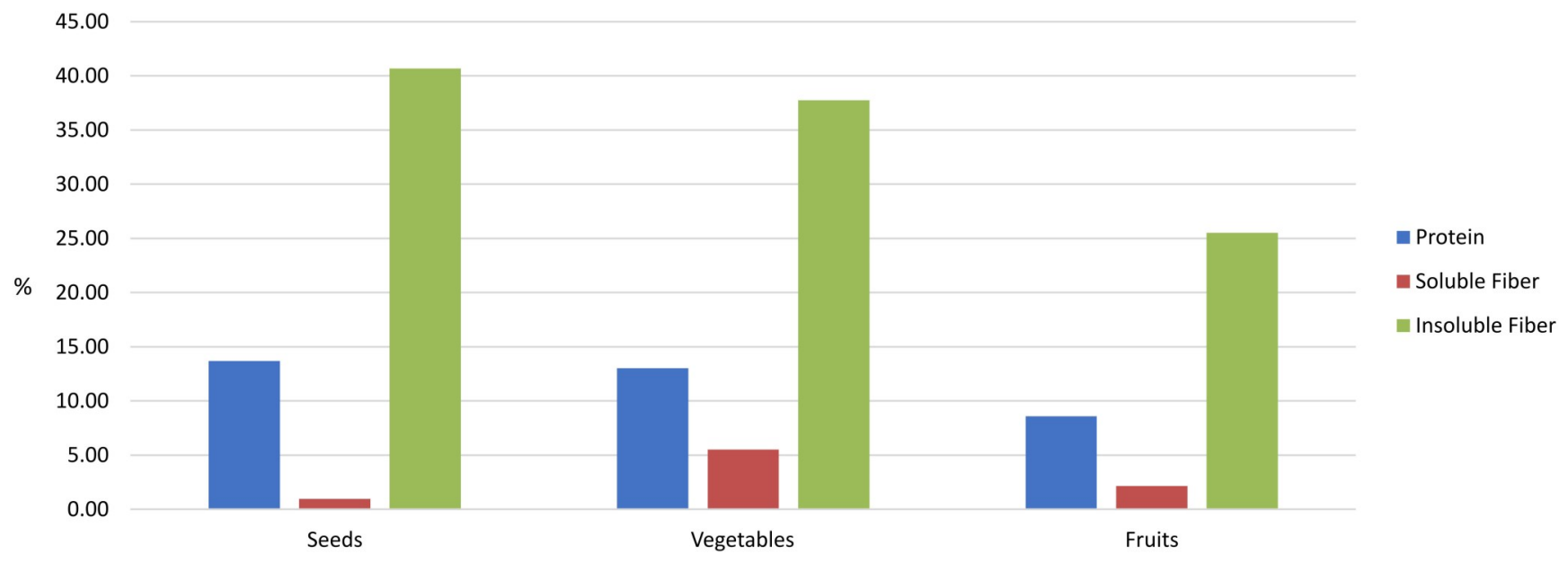

Figure 1 Average percentage values of protein, soluble fiber, and insoluble fiber for seeds, plant vegetable material, and fruits.

the plant part collected, and the total number of food and medicinal uses listed (Supplementary Table 1).

\section{Species Collection and Analyses}

Plant materials from 50 targeted species were collected in the Midwest, Great Plains, or Southwest during the 2013 growing season, or grown at the Native Medicinal Plant Research Garden (Bosnak et al. 2012). The scientific name, taxonomic authority, plant part collected, voucher specimen number, geographic coordinates, and date of collection for each plant collection were recorded. Voucher specimens were deposited in the R. L. McGregor Herbarium at the University of Kansas.

Appropriate plant parts were prepared for dietary assays by reducing plant material to small pieces and air drying at room temperature. Seed chaff was removed using screens. Crude protein, total dietary fiber, soluble fiber, and insoluble fiber were analyzed for each plant part by the American Institute of Baking in Manhattan, Kansas. They ground the plant material and conducted duplicate fiber and protein analyses on all samples using the following methods:

a. AACC 46-30.01 Crude Protein (standard deviation 0.5)—Combustion Method (based on AOAC Method 992.23). Crude protein was estimated by multiplying nitrogen $(\mathrm{N})$ by a factor of 6.25 .

b. AACC 32-07.01 Soluble, Insoluble, and Total Dietary Fiber (Enzymatic gravimetric method, MES-Tris buffer; standard deviation 1.0). This corresponds to AOAC Method 991.43.

Duplicate tests were averaged from each sample. We grouped material by seeds, vegetable material (e.g., roots, leaves, and shoots), or fruits and calculated average protein and fiber content for each group. When possible, we compared values of protein and dietary fiber from plant parts we tested to values for plant-based foods that are commonly consumed in the United States. To do this, we searched for commonly consumed plant-based foods in the USDA National Nutrient Database (2016), recorded protein and dietary fiber values listed in the database, and compared them to results from our species. Protein and dietary fiber values in the USDA database were presented in grams per 100 grams of plant material. USDA database values were converted to percentages

Table 1 Average (range) percentage values of protein, total dietary fiber, soluble fiber, and insoluble fiber for seeds, plant vegetable material, and fruits.

\begin{tabular}{llllll}
\hline & N & Protein & Total Dietary Fiber & Soluble Fiber & Insoluble Fiber \\
\hline Seeds & 17 & $13.70(4.66-26.53)$ & $41.64(4.26-64.41)$ & $0.97(0.00-9.42)$ & $40.67(3.83-64.41)$ \\
Vegetable & 25 & $13.04(2.40-36.72)$ & $43.76(5.80-72.36)$ & $5.53(1.00-22.72)$ & $37.74(2.75-71.17)$ \\
Fruits & 8 & $8.60(2.43-13.47)$ & $27.65(7.32-45.03)$ & $2.15(0.00-5.64)$ & $25.52(6.27-45.03)$ \\
\hline
\end{tabular}




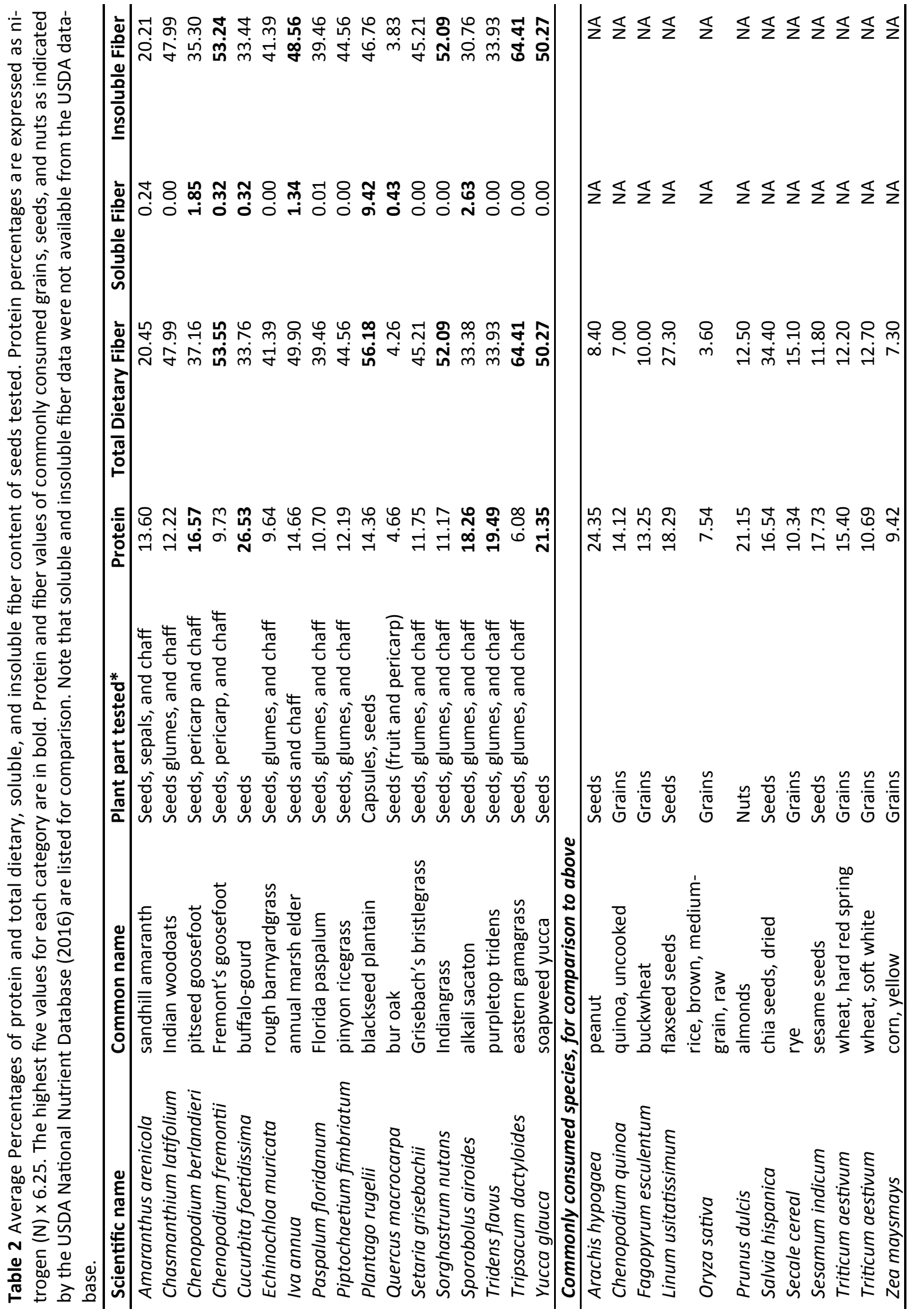


for comparison to our results, which were analyzed as percentages. Protein values from the USDA database that consisted of multiplying $\mathrm{N}$ by a factor other than 6.25 are indicated as such. A limitation of this approach is that protein and fiber percentages of our plant materials were analyzed and reported on a $100 \%$ dry matter basis, but the USDA database typically reports data for foods in the form in which they are consumed. Therefore, we report commonly consumed food data for grains, seeds, and dried fruits only, to be most comparable to our results. We do not report commonly consumed vegetable data, since none of the vegetable data from the USDA database are reported on a dry matter basis.
Results

We found that many plants contained high amounts of protein and fiber (Tables 1-7), with seeds having the greatest levels of protein and insoluble fiber (Figure 1). On average, seeds contained 5\% higher protein content than vegetables and 59\% higher protein content than fruits (Table 1). Total dietary fiber often closely ranked with insoluble fiber levels. Vegetables contained 5\% higher total dietary fiber values than seeds and $58 \%$ higher total dietary fiber values than fruits (Table 1). Soluble fiber was nearly six and three times higher on average in vegetables than in seeds and fruits, respectively, and insoluble fiber was $8 \%$ and $59 \%$ higher in seeds than in

Table 3 Percentages of protein and total dietary, soluble, and insoluble fiber content of vegetable parts tested from native or naturalized plants. Values for all protein and fiber are averages from duplicate tests. Protein percentages are expressed as nitrogen $(\mathrm{N}) \times 6.25$. The highest five values for each category are in bold. No dried vegetable species (except potato listed below) were available for comparison in the USDA National Nutrient Database (2016).

\begin{tabular}{|c|c|c|c|c|c|c|}
\hline Scientific name & Common name & Plant part tested & Protein & $\begin{array}{r}\text { Total Dietary } \\
\text { Fiber }\end{array}$ & $\begin{array}{r}\text { Soluble } \\
\text { Fiber }\end{array}$ & $\begin{array}{r}\text { Insoluble } \\
\text { Fiber }\end{array}$ \\
\hline Achillea millefolium & common yarrow & Leaves & 16.41 & 46.70 & 7.99 & 38.71 \\
\hline Amaranthus palmeri & carelessweed & Leaves & 32.17 & 46.90 & 9.59 & 23.45 \\
\hline Artemisia dracunculus & wormwood & $\begin{array}{l}\text { Leaves, flowering } \\
\text { buds }\end{array}$ & 15.97 & 49.56 & 7.84 & 41.73 \\
\hline Asclepias syriaca & common milkweed & $\begin{array}{l}\text { Young flower } \\
\text { heads in bud }\end{array}$ & 20.63 & 37.03 & 4.71 & 32.33 \\
\hline Callirhoe involucrata & purple poppy mallow & Roots & 6.89 & 34.45 & 1.00 & 33.45 \\
\hline Camassia angusta & prairie camas & Bulbs & 4.41 & 39.32 & 22.72 & 16.60 \\
\hline Chenopodium album & lambsquarters & Leaves & 24.86 & 34.93 & 4.04 & 30.89 \\
\hline Cichorium intybus* & chicory & Roots & 2.40 & 38.59 & 4.72 & 33.88 \\
\hline Cirsium altissimum & tall thistle & Leaves & 16.91 & 48.67 & 4.68 & 44.01 \\
\hline Cirsium undulatum & wavyleaf thistle & Roots & 7.80 & 59.80 & 2.23 & 57.57 \\
\hline Dalea candida & white prairie clover & Roots & 5.42 & 72.36 & 1.20 & 71.17 \\
\hline Echinacea angustifolia & echinacea & $\begin{array}{l}\text { Stems, leaves, } \\
\text { flower heads }\end{array}$ & 6.80 & 58.87 & 1.63 & 57.24 \\
\hline Ephedra trifurca & longleaf jointfir & Stems and leaves & 7.01 & 59.93 & 1.80 & 58.14 \\
\hline Gaura parviflora & velvetweed & Roots & 3.61 & 70.35 & 2.30 & 68.06 \\
\hline Glycyrrhiza lepidota & American licorice & Roots & 10.37 & 53.10 & 1.45 & 52.38 \\
\hline Helianthus tuberosa & Jerusalem-artichoke & Tubers & 12.55 & 5.80 & 3.05 & 2.75 \\
\hline Lactuca canadensis & Canada lettuce & Leaves & 16.97 & 41.08 & 7.34 & 33.74 \\
\hline Ligusticum porteri & oshá & Leaves & 15.18 & 46.23 & 8.22 & 38.01 \\
\hline Mentha spicata* & spearmint & Leaves, stems & 5.98 & 53.30 & 3.44 & 49.86 \\
\hline Oenothera biennis & evening primrose & Leaves & 11.78 & 12.45 & 4.10 & 8.36 \\
\hline Portulaca oleracea & little hogweed & $\begin{array}{l}\text { Leaves, stems, } \\
\text { flowers, seeds }\end{array}$ & 10.06 & 55.55 & 5.60 & 49.95 \\
\hline $\begin{array}{l}\text { Solanum tuberosum* } \\
\text { (for comparison) }\end{array}$ & potato & Roots (tubers) & 8.22 & 7.10 & NA & NA \\
\hline Taraxacum officinale * & dandelion & Roots & 4.86 & 31.90 & 16.20 & 15.70 \\
\hline Trifolium pretense* & red clover & Flower heads & 18.41 & 41.13 & 3.11 & 38.86 \\
\hline Urtica dioica & nettle & Leaves & 36.72 & 40.93 & 5.46 & 35.47 \\
\hline
\end{tabular}


Table 4 Percentages of protein and total dietary, soluble, and insoluble fiber content of fruits tested from native or naturalized plants. Values for all protein and fiber are averages from duplicate tests. Protein percentages are expressed as nitrogen $(\mathrm{N}) \times 6.25$. The highest five values for each category are in bold. Protein and fiber values of commonly consumed dried fruits as indicated by the USDA National Nutrient Database (2016) are listed for comparison. Note that soluble and insoluble fiber data were not available from the USDA database.

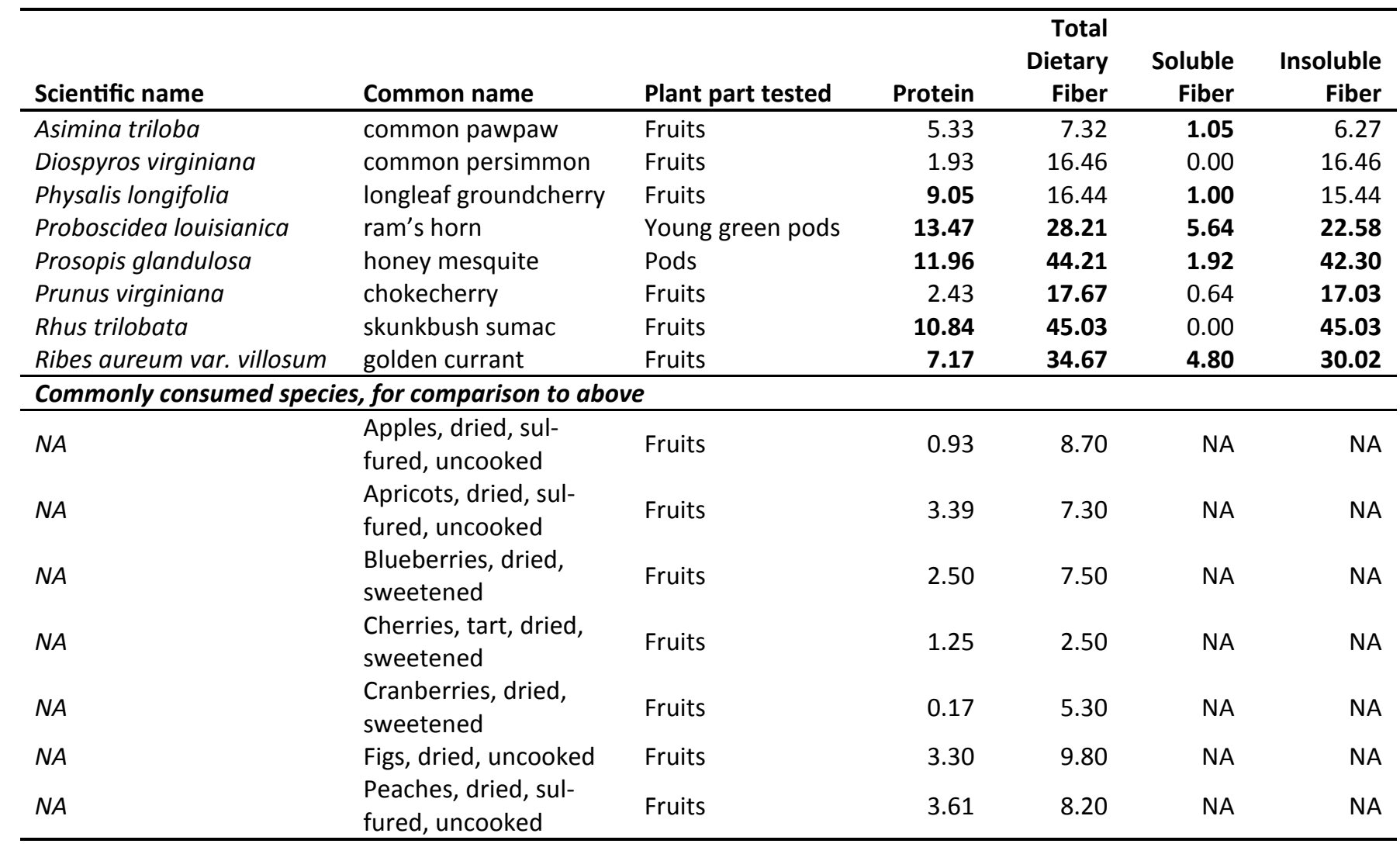

vegetables and fruits, respectively. The highest ranked species within each food group often had higher or comparable values of protein and fiber compared to values of similar commonly consumed plant-based foods (Tables 2 and 4). Out of all species tested, nettle (Urtica dioica) leaves had the highest percentage of protein (Table 5), white prairie clover (Dalea candida) roots had the highest percentage of total dietary and insoluble fiber (Table 6), and prairie camas (Camassia angusta) bulbs had the highest percentage of soluble fiber. Overall, blackseed plantain (Plantago rugelii) had the highest combined ranks of percent protein, soluble fiber, and insoluble fiber (Table 7).

Seeds

Many of the seeds tested had very high protein and fiber content compared to commonly consumed species (Table 2). Buffalo gourd (Cucurbita foetidissima) seeds had the highest protein content, which was higher than any of the commonly consumed species. Soapweed yucca (Yucca glauca) had the second highest

Table 5 Plants with the highest percentages of protein.

\begin{tabular}{llll}
\hline Scientific name & Common name & Plant part tested & Average Protein \\
\hline Urtica dioica & nettle & Leaves & 36.72 \\
Amaranthus palmeri & carelessweed & Leaves & 32.17 \\
Cucurbita foetidissima & buffalo-gourd & Seeds & 26.53 \\
Chenopodium album & lambsquarters & Leaves & 24.86 \\
Yucca glauca & soapweed yucca & Seeds & 21.35 \\
Asclepias syriaca & common milkweed & Flower heads & 20.63 \\
\hline
\end{tabular}


Table 6 Plants with the highest percentages of soluble and insoluble fiber. Those plants with the highest levels of insoluble fiber also had the highest levels of total dietary fiber.

\begin{tabular}{|c|c|c|c|c|c|}
\hline Scientific Name & Common Name & Plant part tested & $\begin{array}{r}\text { Soluble } \\
\text { Fiber }\end{array}$ & $\begin{array}{r}\text { Insoluble } \\
\text { Fiber }\end{array}$ & $\begin{array}{r}\begin{array}{r}\text { Total Dietary } \\
\text { Fiber }\end{array}\end{array}$ \\
\hline \multicolumn{6}{|l|}{ Top 6 Insoluble Fiber } \\
\hline Dalea candida & white prairie clover & Roots & 1.20 & 71.17 & 72.36 \\
\hline Gaura mollis & velvetweed & Roots & 2.30 & 68.06 & 70.35 \\
\hline Tripsacum dactyloides & eastern gamagrass & Seeds & 0.00 & 64.41 & 64.41 \\
\hline Ephedra trifurca & longleaf jointfir & Stems & 1.80 & 58.14 & 59.93 \\
\hline Cirsium undulatum & wavyleaf thistle & Roots & 2.23 & 57.57 & 59.80 \\
\hline Echinacea angustifolia & echinacea & $\begin{array}{l}\text { Stems, leaves, flower } \\
\text { heads }\end{array}$ & 1.63 & 57.24 & 58.87 \\
\hline \multicolumn{6}{|l|}{ Top 6 Soluble Fiber } \\
\hline Camassia scilloides & prairie camas & Roots & 22.72 & 16.60 & 39.32 \\
\hline Taraxacum officinale - Colo & dandelion & Roots & 16.20 & 15.70 & 31.90 \\
\hline Amaranthus palmeri & carelessweed & Leaves & 9.59 & 23.45 & 46.90 \\
\hline Plantago rugelii & blackseed plantain & Seeds & 9.42 & 46.76 & 56.18 \\
\hline Ligusticum porteri & oshá & Leaves & 8.22 & 38.01 & 46.23 \\
\hline Achillea millefolium & common yarrow & Leaves & 7.99 & 38.71 & 46.70 \\
\hline
\end{tabular}

protein content, which was closely aligned with protein content of almonds. Purpletop tridens (Tridens flavus), alkali sacaton (Sporobolus airoides), and pitseed goosefoot also ranked high in protein. Bur oak (Quercus macrocarpa), eastern gamagrass (Tripsacum dactyloides), rough barnyardgrass (Echinochloa muricata), and Fremont's goosefoot (Chenopodium fremontii) ranked lowest (less than 10\%) in protein for seeds, near the value for yellow corn.

Twelve of the seventeen species' seeds tested had total dietary fiber values higher than commonly consumed species. The highest value was found in eastern gamagrass seed, which had nearly double the total dietary fiber of chia (Salvia hispanica) seeds. Blackseed plantain, Fremont's goosefoot, Indian grass (Sorghastrum nutans), and soapweed yucca, along with several other species, also had very high values. Eastern gamagrass, Fremont's goosefoot, Indiangrass, and soapweed yucca also ranked high in insoluble fiber, as did annual marsh elder (Iva annua). Blackseed plantain had the highest percentage of soluble fiber, which was over 3.5 times higher than the next highest species, alkali sacaton. Pitseed goosefoot and bur oak ranked third and fourth highest for soluble fiber and Fremont's goosefoot and buffalo gourd seeds tied in rank for fifth. Eight species of seeds did not contain any soluble fiber. Bur oak ranked poorly overall in total dietary and insoluble fiber compared to the other native species, with a total dietary fiber content similar to commonly consumed medium grain raw brown rice.

Table 7 Top 10 plants that ranked highest for both protein and fiber content. Plants were ranked independently for percent protein, soluble fiber, and insoluble fiber, then ranked by the sum of the three independent ranks.

\begin{tabular}{lll}
\hline Scientific Name & Common Name & Rank \\
\hline Plantago rugelii & blackseed plantain & 1 \\
Urtica dioica & nettle & 2 \\
Artemisia dracunculus & wormwood & 3 \\
Amaranthus palmeri & carelessweed & 4 \\
Achillea millefolium & common yarrow & 5 \\
Cirsium altissimum & tall thistle & 6 \\
Ligusticum porteri & oshá & 7 \\
Lactuca canadensis & Canada lettuce & 8 \\
Trifolium pratense & red clover & 9 (tie) \\
Portulaca oleracea & little hogweed & 9 (tie) \\
\hline
\end{tabular}




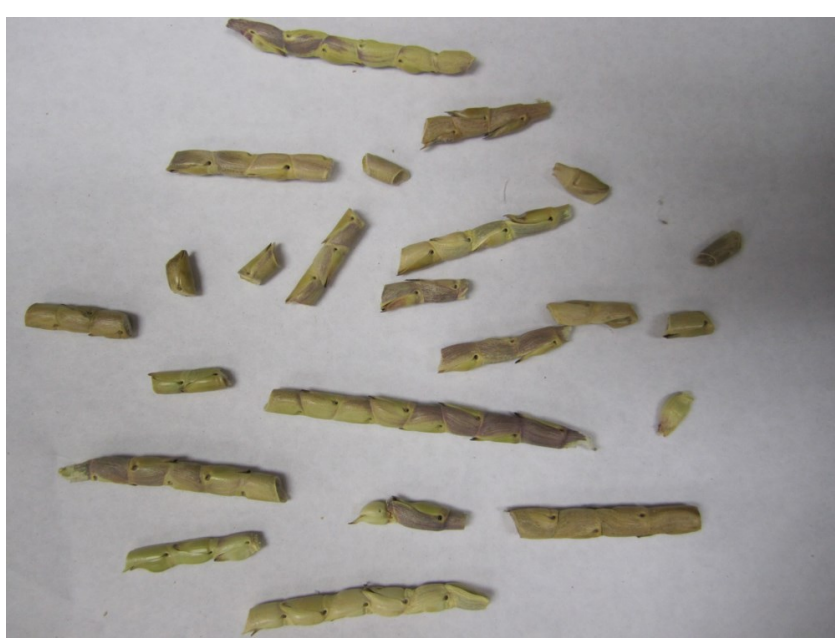

Figure 2 Eastern gamagrass (Tripsacum dactyloides) seeds still joined together and as individuals.

\section{Vegetables}

Many species for which we tested leaves, tubers, roots, or other vegetative parts (i.e., vegetables) had very high protein and fiber content (Table 3). Species with high protein content did not necessarily have high fiber content, and vice-versa. Nettle leaves contained the highest percentage of protein, followed by carelessweed (Amaranthus palmeri) leaves, lamsquarters leaves, young common milkweed flower heads, and red clover (Trifolium pretense) flower heads. Chicory (Cichorium intybus) roots contained the lowest protein percentage, followed by velvetweed (Gaura parviflora) roots, prairie camas bulbs, dandelion (Taraxacum officianalis) roots, white prairie clover roots, spearmint (Mentha spicata) leaves and stems, echinacea (Echinacea angustifolia) stems, leaves, and flower heads, purple poppy mallow (Callirhoe involucrata) roots, longleaf jointfir (Ephedra trifurca) stems and leaves, and wavyleaf thistle (Cirsium undulatum) roots. These all contained less than $10 \%$ protein.

White prairie clover roots, velvetweed roots, longleaf jointfir stems and leaves, wavyleaf thistle roots, and echinacea stems, leaves, and roots had the highest total dietary fiber and insoluble fiber values. Velvetweed roots and white prairie clover roots had higher values of total dietary and insoluble fiber than any other vegetable, seed, or fruit tested. Prairie camass had extraordinarily high soluble fiber content, much higher than dandelion roots or carelessweed leaves, which ranked second and third highest, respectively. Oshá (Ligusticum porteri), also called Porter's licorice root, leaves and common yarrow leaves ranked fourth and fifth in soluble fiber.
Fruits

All but two species of fruit tested had higher values of protein than commonly consumed dried fruits, and all but one had substantially higher values of total dietary fiber than commonly consumed species (Table 4). Young green pods of ram's horn (Proboscidea lonisianica) were the top source of protein out of all fruits, followed closely by honey mesquite (Prosopis glandulosa), skunkbush sumac (Rhus trilobata), longleaf groundcherry (Physalis longifolia), and golden currant (Ribes aureum var. villosum). These species contained nearly or over double the percent protein of all commonly consumed species.

Skunkbush sumac fruits contained the highest total dietary fiber content, all of which was the insoluble form. Honey mesquite pods contained the second highest percentage of total dietary fiber and insoluble fiber. Ram's horn pods were the top source of soluble fiber, followed by golden currant, honey mesquite, common pawpaw (Asimina triloba), and longleaf groundcherry.

\section{Discussion}

We found that many seeds, vegetable material, and fruits, both native and a few naturalized foods, contained very high amounts of protein and fiber. In many cases, foods we tested contained higher amounts of protein and fiber than comparable commonly consumed foods, particularly for seeds and fruits. This indicates great potential for using these wild foods to increase protein and fiber intake both in traditional cultures and the general population. Ethnobotanical properties and cultivation potential of top ranked plants are discussed below.

Also four notable species are discussed below because they have potential to benefit health based on their high protein and fafiber values relative to commonly consumed foods and could be simultaneously valuable from an economic perspective pending further research on production and harvest.

\section{Seeds}

Eastern gamagrass is a notable species (Figure 2), with a long history as food, and once considered as a possible progenitor of corn (Eubanks 1997), though recent evidence suggests it is not (Matsuoka et al. 2002). It is native to tallgrass prairies of the central United States and into central Mexico. The seeds have an ancient use as food and were found stored in bundles in the remains of Ozark Bluff-dwellers cave 


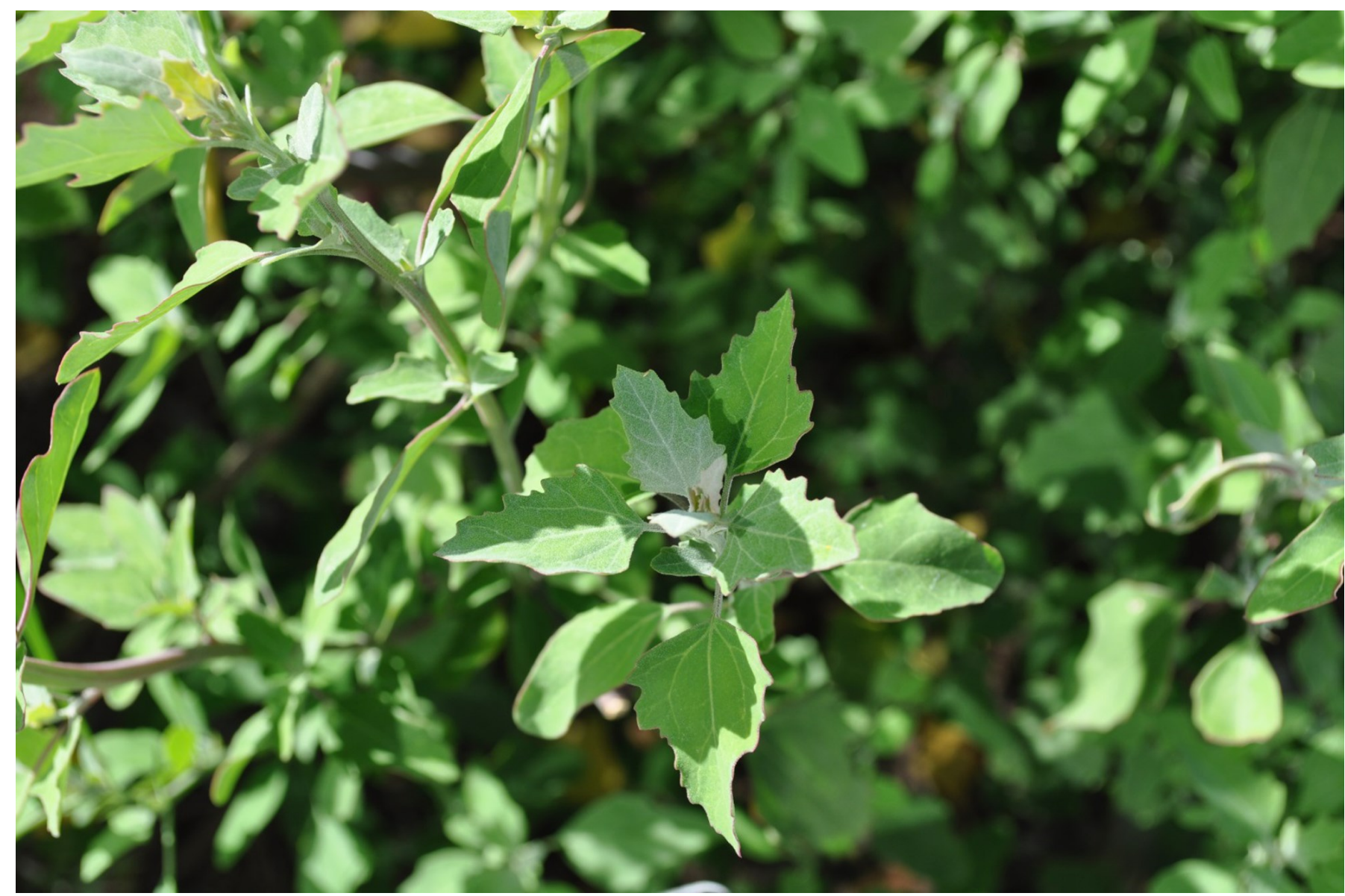

Figure 3 Pitseed goosefoot or lambsquarters (Chenopodium berlandieri) leaves and young shoots.

habitations (Gilmore 1931), which may be 2,000 years old. However, the seeds are hard to prepare because the hulls are very tough and thick. We ground up both the hull and endosperm for testing, which resulted in our highest amount of total dietary fiber. This plant has been studied by the Land Institute in Salina, Kansas as a possible perennial grain crop (Jackson 2002; Jackson and DeWald 1994). It is an important forage crop and seeds are available through commercial sources. While not nearly as productive as corn, it has seeds about a fourth the size of corn and production techniques have been established as it is harvested mechanically for the native grass seed industry.

Buffalo gourd, which contained the highest protein content, is a common perennial plant in disturbed areas throughout the west and is a wild gourd or squash for which both root and seeds were consumed by indigenous people (Bemis et al. 1978). It contains bitter compounds, so desirability is likely lower. Production of small fruits is substantial and would be similar to pumpkin in that seeds would have to be removed from small fruits, cleaned, and dried. The high-protein seeds of soapweed yucca also have undesirable compounds (saponins) that add a soapy taste to the seeds (Kindscher 1987). Purpletop tridens is a common grass of prairies and old fields and could be readily cultivated and harvested mechanically, similarly to how other native grass seed is produced. It does not have a specific tribal use, but like most all native grasses it was gathered as food (Kindscher 1987). The seeds are somewhat smaller than commercial millet seeds. Alkali sacaton seeds were gathered as food by Hopi and other Indians in the western United States (Whiting 1939), but they are very small and the grass is typically found on alkali and salt-effected soils. Pitseed goosefoot seeds and greens were widely used as food (Fritz el al. 2017).

Other species of seeds had high fiber values. Blackseed plantain is closely related to European plantains, which have high fiber values (Sosulski and Cadden 1982). Fremont's goosefoot was used 


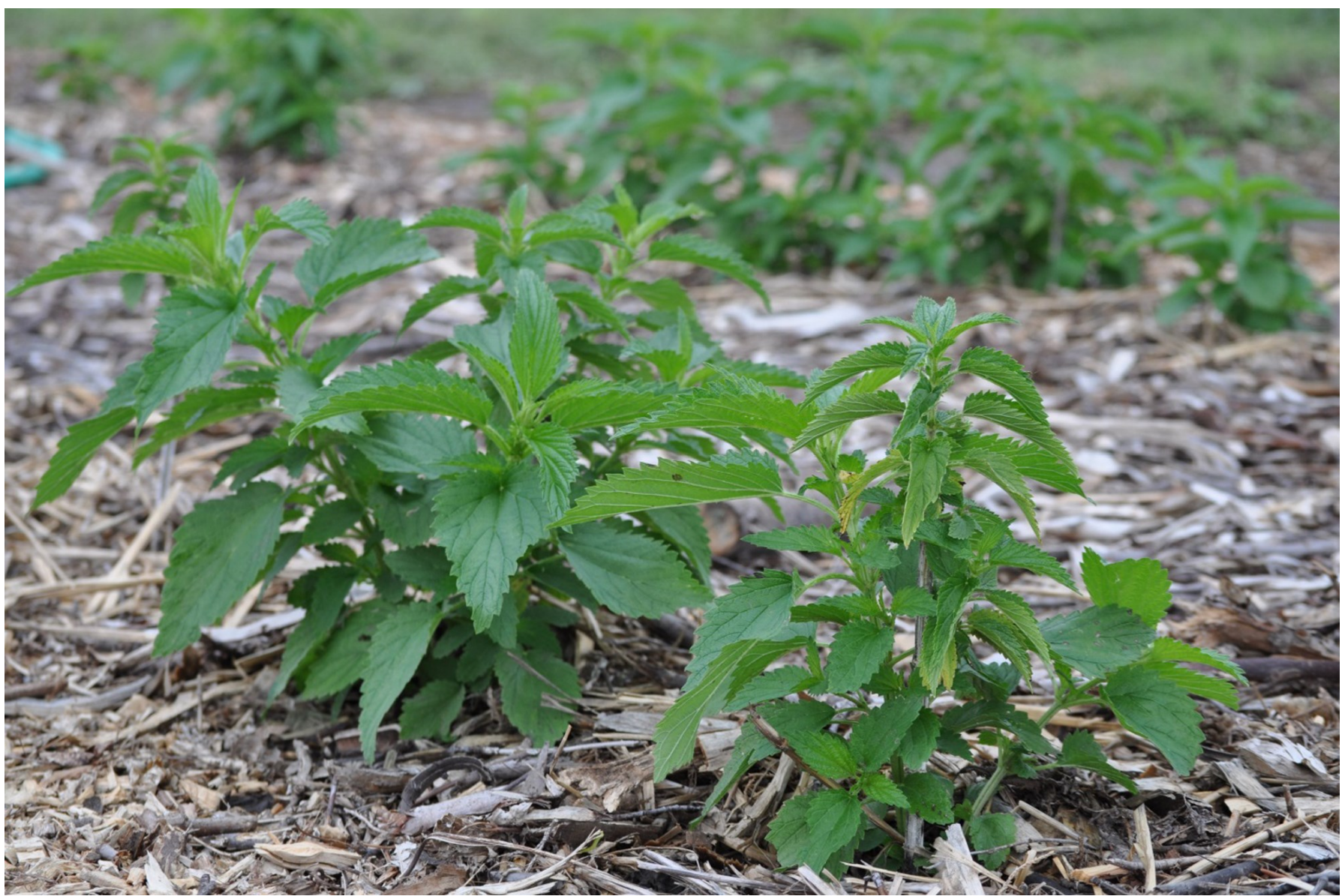

Figure 4 Nettles (Urtica dioca) leaves and young shoots growing in our mulched research garden.

(historically) interchangeably with pitseed goosefoot. Indiangrass is a native tall grass that is used in conservation plantings and the seeds are already cultivated. However, the seeds are relatively small. Finally, annual marsh elder, an important prehistoric Midwestern food (Black 1963) is not very suitable for cultivation as its pollen can produce allergic reactions, much like the closely-related ragweed (Ambrosia) species (Epstein 1960).

\section{Vegetables}

Pitseed goosefoot (Chenopodium berlandieri) is a notable species (Figure 3) as its leaves ranked high in protein. This native annual is highly productive and harvest could be mechanized, much like alfalfa hay for dried greens. It should be noted that closely related quinoa (Chenopodium quinoa), which is somewhat more productive, is currently being grown commercially in the San Juan valley of Colorado for its seeds. And the greens could be harvested in great quantity, treating it like a hay crop with mechanical harvest. Its history of use by Native Americans is likely under-reported because wild greens were not sufficiently investigated at the time of contact (Kindscher 1987). In addition, the species are easily confused, so taken together the following tribes used Chenopodium greens: Alaskan Natives, Apache, Cherokee, Hopi, Iroquois, Kiowa, Lakota, Sioux, Miwok, Navaho, Ojibwa, Omaha, Paiute, Papago, Pawnee, Pima, Potawatomi, and Zuni (Kindscher 1987; Moerman 2011). Seeds of Chenopodium species were recognized by the Zuni as one of their ancient foods (Stevenson 1915). The seeds show up in numerous archeological sites, some dating to several thousand years ago, and the species was a cultivar of the Eastern Agricultural Complex (Asch and Asch 1977; Fritz and Smith 1988).

The leaves of nettles (Urtica dioica), another notable species (Figure 4), had the highest protein value and have numerous uses as food and medicine in both the Old and New Worlds (Moerman 2013 lists 222 uses). Nettle (Urtica dioica) is a well-known species native to both Eurasia and North America. It was used extensively across America as food by the 


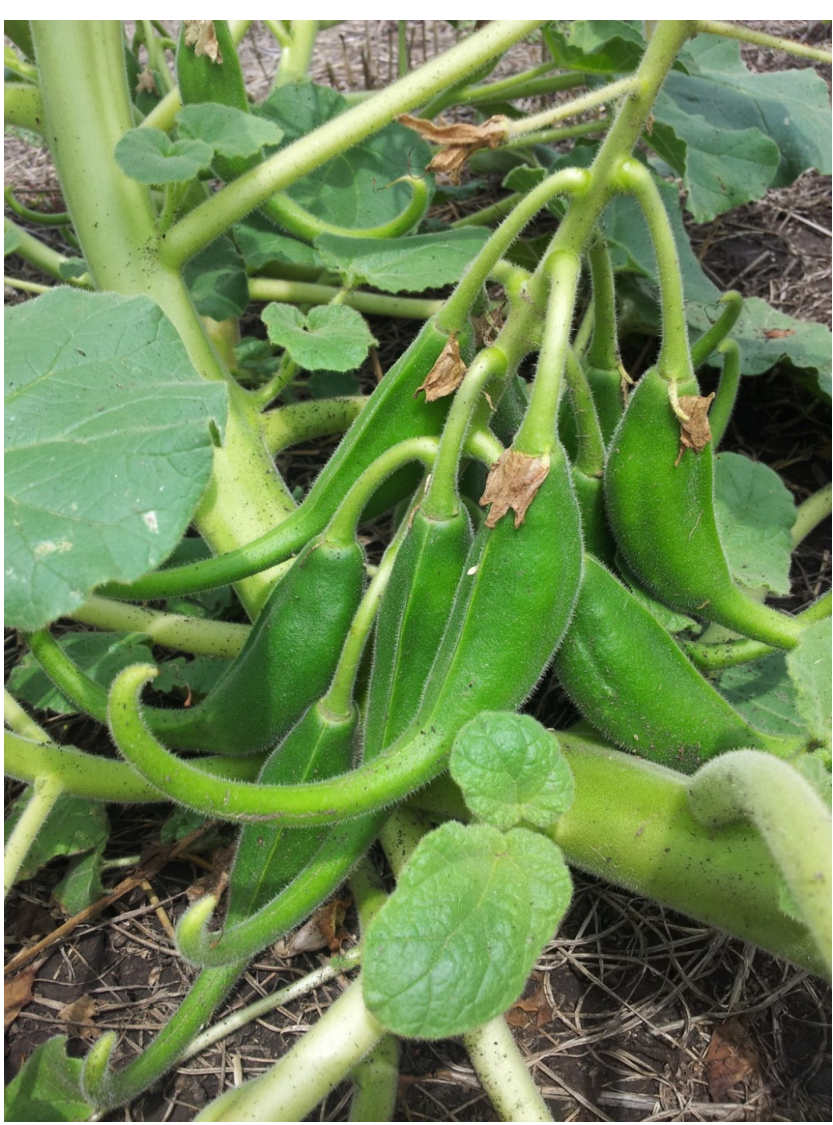

Figure 5 Ram's horn (Proboscidea louisianica) pods ready to eat.

Iroquois and Mohegans in the Northeast, the Skagit, Makah, and Hoh in the Northwest, and Alaskan Natives (Moerman 2013). The plants are a highly productive perennial, inhabit wet/moist soils, easily cultivated, and very large yields could be harvested with equipment, similar to that used for alfalfa. They have a unique taste that is rich and pleasant.

Carelessweed, (Amaranth palmeri), was used as a cooked green and the seeds were valuable to Native Americans as food (Kindscher 1987). Common milkweed flower buds or young leafy tops are an important cultural food today for use in soup among the Potawatomi, Omaha, and Winnebago in our region (Gilmore 1977; Kindscher 1987). Red clover flower heads are also widely used in teas and tea blends.

Other species contained high amounts of fiber. White prairie clover roots were used as food and as a sweetener (Kindscher 1987), but it is slow growing and roots, which are not large, would likely need to grow at least two years before they could be harvested. Velvetweed roots were a minor component in Native American diets (Moerman 2013). Longleaf jointfir was used as a tea plant (Moerman 2013). It tastes like green tea, but lacks caffeine, and is a slowgrowing shrub. Wavyleaf thistle roots have extensive food use and the plants are easily grown. Echinacea, mainly known for its medicinal use (Kindscher 2016), is included in some fruit juices for its healthpromoting properties. It is typically wild-harvested because it grows slowly under cultivation. Also, it has a slightly acrid taste.

Prairie camas has starchy bulbs that were eaten (Thoms 2008). They are closely related to the camass used by Native peoples in the Pacific Northwest. We found no studies that explored cultivating this species. Dandelion roots are not native, but have extensive use by Native Americans and Europeans as food and medicine (Moerman 2013). Carelessweed leaves have considerable soluble fiber, are easy to grow, and quite productive. Oshá leaves are used in the Southwest as a parsley substitute (Kindscher et al. 2013b). Oshá has considerable appeal among Hispanics and Native Americans in the Southwest and Mexico for its medicinal roots. It is rather productive, but only grows at high elevation.

\section{Fruits}

Young green pods of ram's horn (Proboscidea louisianica) (Figure 5) are notable for their pods which when young, were a common cooked vegetable of Native Americans from the Great Plains to the Southwest and were eaten by the Apache (Castetter 1935), Cahuilla, Havasupai, and Papago (Moerman 2013). Ram's horn is an unusual annual plant, with a musty smell and whose mature, curled pods have long claws. The fibers of the mature pods were tough and used in basketry (Kindscher 1987). This plant is a common weed in fields, has substantial yield of its pods, and could be cultivated to have substantial yields per acre, but harvest of it tender young pods might be difficult for mechanical harvest.

Honey mesquite is a small tree of the Southwest plains and deserts and its pods containing young seeds were consumed widely (Castetter 1935). Highly productive in the wild, as trees can produce substantial, but varied, yields, it is proposed as a "new" desert food crop (Hodson 2001). Acidic skunkbush sumac fruits were used as a tart food (Kindscher 1987) and grow on small bushes. Golden current was consumed widely in the Great Plains and Southwest and has been cultivated in a minor fashion, with varieties adapted to home gardens (Kindscher 


\section{Research Communications}

1987). Chokecherries (Prunus virginiana) were the most important wild fruits to Indians of the Great Plains (Kindscher 1987). These shrubs have been cultivated and are relatively productive. Finally, long-leaf ground cherry fruits have been used by many tribes as food in the Great Plains and Southwest and contain potent anti-cancer compounds (Kindscher et al. 2012; Zhang et al. 2011).

\section{Conclusions}

Many of the plants tested contain protein and fiber at amounts superior or comparable to commonly consumed foods. Identification of plant species with novel protein and fiber sources could raise awareness of wild plants and traditional knowledge and cultivation and/or harvest of these plants could become both commercially viable and competitive in the world market. Of particular note is the recognition of indigenous food practices as not only successful, but beneficial to a modern dietary intake. Introducing these indigenous plant foods to the wider public has value beyond simply their appeal as food. Promoting the indigenous origins of the foods acknowledges the subsistence innovations of the Native Americans beyond corn and honors their ancient and traditional knowledge of native foods. It represents another important contribution of Native American culture to the wider world and evidence of their healthier and more sustainable cultural practices. Tribes today may be particularly interested in these plants and how they might be used to improve the health and economic welfare of their Tribal members. For modern use of these plants as foods, future studies on the energy content and economics of cultivation of the plants will be important next steps.

\section{Acknowledgments}

Several staff and students associated with the Kansas Biological Survey helped with this work including Kirsten Bosnak, Rachel Craft, Amy Isenburg, Jessica Lackey, Quinn Long, and Hillary Loring. We appreciated the American Baking Institute office and staff in Manhattan, Kansas who helped us with nutritional testing. Funding for our work was provided by the Kellogg Company and University of Kansas Strategic Initiative.

\section{Declarations}

Permissions: None declared.

Sources of funding: University of Kansas, Strategic Initiative Fund (supporting staff time); and Kellogg
Company (supporting field collection, growing, and lab testing).

Conflicts of Interest: None declared.

\section{References Cited}

Asch, D. L., and N. B. Asch. 1977. Chenopod as Cultigen: A Re-Evaluation of Some Prehistoric Collections from Eastern North America. Midcontinental Journal of Archaeology 2:3-45.

Bemis, W. P., L. D. Curtis, C. W. Weber, and J. Berry. 1978. The Feral Buffalo Gourd, Cucurbita foetidissima. Economic Botany 32:87-95. DOI:10.1007/ BF02906733.

Black, M. 1963. The Distribution and Archaeological Significance of the Marsh elder Iva annua L. Papers of the Michigan Academy of Science, Arts, and Letters 48:541 -547 .

Bosnak, K., K. Kindscher, R. Craft, and B. N.Timmermann. 2012. The University of Kansas School of Pharmacy Medicinal Plant Garden: Case Study of a New Teaching Garden with a History. HerbalGram: The Journal of the American Botanical Council 95:38-45.

Castetter, E. F. 1935. Uncultivated Native Plants Used as Sources of Food. University of New Mexico Bulletin 4:1-44. DOI:10.1007/BF02904415.

Doebley, J. F. 1984. "Seeds" of Wild Grasses: A Major Food of Southwestern Indians. Economic Botany 38:52-64. DOI:10.1007/bf02904415.

Epstein, S. 1960. Role of Dermal Sensitivity in Ragweed Contact Dermatitis. Archives of Dermatology 82:48-55. DOI:10.1001/ archderm.1960.01580010054008.

Eubanks, M. W. 1997. Molecular Analysis of Crosses between Tripsacum dactyloides and Zea diploperennis (Poaceae). Theoretical and Applied Genetics 94:707-712. DOI:10.1007/s001220050469.

Fritz, G. J., M. C. Bruno, B. S. Langlie, B. D. Smith, and L. Kistler. 2017. Cultigen Chenopods in the Americas: A Hemispherical Perspective. In Social Perspectives on Ancient Lives from Paleoethnobotanical Data, edited by M. P. Sayre and M. Bruno, pp. 5575. Springer International Publishing, Gewerbestrasse, Switzerland.

Fritz, G. J., and B. D. Smith. 1988. Old Collections and New Technology: Documenting the 
Domestication of Chenopodium in Eastern North America. Midcontinental Journal of Archaeology 13:3-27.

Gilmore, M. R. 1931. Vegetal Remains of the Ozark Bluff-Dweller Culture. Michigan Academy of Science, Arts and Letters: Papers 14:83-102.

Gilmore, M. R. 1977. Uses of Plants by the Indians of the Missouri River Region. University of Nebraska Press, Lincoln, NE.

Gremillion, K. J. 2004. Seed Processing and the Origins of Food Production in Eastern North America. American Antiquity 69:215-233. DOI:10.2307/4128417.

Hart, J. P., and W. A. Lovis. 2013. Reevaluating What We Know About the Histories of Maize in Northeastern North America: A Review of Current Evidence. Journal of Archaeological Research 21:175216. DOI:10.1007/s10814-012-9062-9.

Hodgson, W. C. 2001. Food plants of the Sonoran Desert. University of Arizona Press, Tucson, AZ.

Jackson, L. L., and C. L. Dewald. 1994. Predicting Evolutionary Consequences of Greater Reproductive Effort in Tripsacum dactyloides, a Perennial Grass. Ecology 75:627-641.

DOI:10.2307/1941721.

Jackson, W. 2002. Natural Systems Agriculture: A Truly Radical Alternative. Agriculture, Ecosystems, and Environment 88:111-117. DOI:10.1016/s0167-8809 (01)00247-x.

Kindscher, K., ed. 2016. Echinacea: Herbal Medicine with a Wild History. Springer, Gewerbestrasse, Switzerland.

Kindscher, K. 1987. Edible Wild Plants of the PrairieAn Ethnobotanical Guide. University Press of Kansas, Lawrence, KS.

Kindscher, K. 1992. Medicinal Wild Plants of the Prairie-An Ethnobotanical Guide. University Press of Kansas, Lawrence, KS.

Kindscher, K., Q. Long, S. Corbett, K. Bosnak, H. Loring, M. Cohen, and B. N. Timmermann. 2012. The Ethnobotany and Ethnopharmacology of Wild Tomatillos, Physalis longifolia Nutt., and Related Physalis Species: A Review. Economic Botany 66:298310. DOI:10.1007/s12231-012-9210-7.

Kindscher, K., S. Corbett, and K. McClure. 2013a. A Statistical Analysis of Medicinal Plants: A Case
Study of Plant Families in Kansas and the Great Plains. Transactions of the Kansas Academy of Science 116:149-155. DOI:10.1660/062.116.0308.

Kindscher, K., J. Yang, Q. Long, R. Craft, and H. Loring. 2013b. Harvest Sustainability Study of Wild Populations of Osha, Ligusticum porteri. Kansas Biological Survey Report No. 176. Kansas Biological Survey, Lawrence, KS.

Kuhnlein, H. V. 2000. The Joys and Pains of Sampling and Analysis of Traditional Food of Indigenous Peoples. Journal of Food Composition and Analysis 13:649-658. DOI:10.1006/jfca.1999.0857.

Matsuoka, Y., Y. Vigouroux, M. M. Goodman, G. J. Sanchez, E. Buckler, and J. Doebley. 2002. A Single Domestication for Maize Shown by Multilocus Microsatellite Genotyping. Proceedings of the National Academy of Sciences of the United States of America 99:6080-6084. DOI:10.1073/pnas.052125199.

Mihesuah, D. A. 2003. Decolonizing Our Diets by Recovering Our Ancestors' Gardens. The American Indian Quarterly 27:807-883. DOI:10.1353/ aiq.2004.0084.

Moerman, D. 2013. Native American Ethnobotany [web page]. Available at: http://naeb.brit.org/. Accessed on April 15, 2013.

Moshfegh, A., J. Goldman, and L. Cleveland. 2005. What We Eat in America: NHANES 2001-02: Usual Nutrient Intake from Foods as Compared to Dietary Reference Intakes. U.S. Department of Agriculture, Agricultural Research Service. Available at: https://www.ars.usda.gov/ ARSUserFiles/80400530/pdf/0102/ usualintaketables2001-02.pdf. Accessed on February 20, 2012.

Nestle, M. 2006. What to Eat. North Point Press, New York.

Phillips, K. M., P. R. Pehrsson, W. W. Agnew, A. J. Scheett, J. R. Follett, H. C. Lukaski, and K. Y. Patterson. 2014. Nutrient Composition of Selected Traditional United States Northern Plains Native American Plant Foods. Journal of Food Composition and Analysis 34:136-152. DOI:10.1016/ j.jfca.2014.02.010.

Preissel, U., and H. G. Preissel. 2002. Brugmansia and Datura: Angel's Trumpets and Thorn Apples. Firefly Books, Buffalo, NY. 
Sanchez, A. 2007. The Teeth of the Lion: The Story of the Beloved and Despised Dandelion. McDonald and Woodward, Newark, OH.

Scarry, C. M., and J. F. Scarry. 2005. Native American "Garden Agriculture" in Southeastern North America. World Archaeology 37:259-274. DOI:10.1080/00438243500095199.

Slavin, J. L. 2008. Position of the American Dietetic Association: Health Implications of Dietary Fiber. Journal of the American Dietetic Association 108:17161731. DOI:10.1016/j.jada.2008.08.007.

Sosulski, F. W., and A. M. Cadden. 1982. Composition and Physiological Properties of Several Sources of Dietary Fiber. Journal of Food Science 47:14721477. DOI:10.1111/j.1365-2621.1982.tb04964.x.

Smith, B. D. 1989. Origins of Agriculture in Eastern North America. Science 246:1566-1571.

DOI:10.1126/science.246.4937.1566.

Smith, B. D., and R. A. Yarnell. 2009. Initial Formation of an Indigenous Crop Complex in Eastern North America at 3800 B.P. Proceedings of the National Academy of Sciences 106:6561-6566. DOI:10.1073/pnas.0901846106.

Stevenson, M. C. 1915. Ethnobotany of the Zuni Indians: Medical practices and Medicinal Plants. Thirtieth Annual Report of the Bureau of American Ethnology 30:39-64.

Thoms, A. V. 2008. Ancient Savannah Roots of the Carbohydrate Revolution in South-Central North America. Plains Anthropologist 53:121-136. DOI:10.1179/pan.2008.008.
USDA. 2013. Dr. Duke's Phytochemical and Ethnobotanical Databases [web page]. Available at: https://phytochem.nal.usda.gov/phytochem/ search. Accessed on December 21, 2013.

USDA. 2014. The PLANTS Database [web page]. Available at: http://plants.usda.gov. Accessed on April 15, 2014.

USDA. 2016. USDA National Nutrient Database for Standard Reference, Release 28 [web page]. Available at: https://www.ars.usda.gov/northeastarea/beltsville-md/beltsville-human-nutritionresearch-center/nutrient-data-laboratory/docs/usda -national-nutrient-database-for-standard-reference/. Accessed on February 27, 2017.

U.S. Department of Health and Human Services and U.S. Department of Agriculture. 2015. 2015-2020 Dietary Guidelines for Americans, $8^{\text {th }}$ Edition [web page]. Available at: http://health.gov/ dietaryguidelines/2015/guidelines/. Accessed on May 4, 2017.

Whiting, A. F. 1939. Ethnobotany of the Hopi. Museum of Northern Arizona Bulletin no. 15. Northern Arizona Society of Science and Art.

Zhang, H., J. Bazzill, R. J. Gallagher, C. Subramanian, P. T. Grogan, V. W. Day, K. Kindscher, M. S. Cohen, and B. N. Timmermann. 2013. Antiproliferative Withanolides from Datura wrightii. Journal of Natural Products 76:445-449. DOI:10.1021/ np300766p.

Supplementary Files available at ojs.ethnobiology.org/index.php/ ebl/article/view/1219 